\title{
Sekundární prevenci CMP je třeba zahájit co nejdříve
}

Cévní mozková príhoda (CMP) je v České republice druhou nejčastější př́činou úmrtí a nejčastější př́ičinou invalidity. $V$ roce 2007 zemřelo na CMP přes 11000 lidí a vyžádala si kolem 40000 hospitalizací. Existuje zde přitom velký prostor, jak tuto enormní zátěž snížit - a ten nabízí dokonalejší antikoagulační léčba u pacientů s fibrilací síní. Tomuto tématu bylo věnováno $i$ jedno ze satelitních symposií v rámci květnového $X X$. výročního sjezdu České kardiologické společnosti v Brně. Akce byla podpořena aliancí společností Bristol-Myers Squibb a Pfizer.

Na vztah mezi fibrilací síní a tromboembolickými (TE) príhodami se nejdřive z pohledu kardiologa zaměřil prof. MUDr. Jaromír Hradec, CSc., ze III. interní kliniky 1. LF UK a VFN v Praze. Připomněl, že fibrilace síní je nejčastěji se vyskytující arytmií, pomineme-li síňové a komorové extrasystoly. Prevalence v populaci je asi 1,5 \% (v České republice tedy žije na 150000 osob s tímto onemocněním). Roste $s$ věkem exponenciálně, do 60 let je kolem $1 \%$, nad 80 let se vyšplhá nad $10 \%$. Podle evropské populační studie, která měla téměř 7000 účastníkủ, onemocní fibrilací síní během svého života každý čtvrtý člověk starší 40 let. Ve všech věkových kategoriích je prevalence mírně vyšší u žen. „Protože populace stárne a umíme lépe léčit akutní stavy, přibývá chronicky nemocných - a platí to i zde. Můžeme tedy očekávat, že počet pacientů s fibrilací síní nadále poroste. Do roku 2050, tedy za necelých 40 let, se minimálně zdvojnásobí," upozorňuje J. Hradec.

Nová evropská doporučení rozeznávají celkem pět klinických typů fibrilace síní - poprvé diagnostikovanou, paroxysmální, dále perzistující, která trvá déle než 48 hodin, ale může být ukončena kardioverzí, dalším typem je dlouhodobě perzistující, trvající déle než rok, u které však stále přetrvává snaha obnovit sinusový rytmus, a nakonec permanentní, kde už byla snaha o obnovení sinusového rytmu ukončena.

\section{Jednoznačně protrombogenní stav}

Dlouho byla fibrilace síní považována za relativně benigní arytmii. To se však zásadně změnilo. Důvody, proč i zde má razantní terapie své místo, jsou mnohé: „Patří mezi ně subjektivní nepř́ijemné potíže, negativní hemodynamické důsledky, které mohou vyústit až v srdeční selhávání nebo tachyarytmickou kardiomyopatii a zejména výrazně zvýšené riziko tromboembolických příhod," říká J. Hradec. Součástí léčby fibrilací síní je tzv. upstream terapie, tedy prevence jejího vzniku. „Některé metaanalýzy vkládaly naděje do blokátorů RAAS a statinů, bohužel klinické studie, které byly na řešení tohoto problému zaměřené a jsou již ukončené, vyšly negativně. Pokud ,upstream' terapie selže a pacient fibrilaci již má, tak se především snažíme obnovit a udržet sinusový rytmus. Možností, jak zasáhnout, máme několik - farmakoterapii, elektrickou kardioverzi a čím dál tím více a úspěšněji využíváme katetrizační ablaci. Jestliže jsme i zde neúspěšní, kontrolujeme srdeční frekvenci," vysvětluje J. Hradec a dodává, že srdeční frekvenci je možné kontrolovat beta-blokátory, verapamilem, digoxinem či jejich kombinacemi.

Vždy je třeba mít na paměti, že fibrilace síní je jednoznačně protrombogenní stav. Tromby vznikají nejčastěji v síních, zejména v jejich oušcích. Při fibrilaci v nich stagnuje krev, mění se její reologické vlastnosti a stává se trombogenní. Trombus se pak může, například při obnově sinusového rytmu, odtrhnout a vmést do systémového oběhu, nejčastěji do mozkových tepen. Fibrilace síní tak riziko vzniku CMP zvyšuje pětkrát a je odpovědná za celou pětinu ischemických mozkových príhod. Nemocný s fibrilací síní, který není antikoagulován, má každý rok 5\% riziko, že dostane CMP. Ikty, které vznikají v důsledku fibrilace síní, mají navíc horší prognózu než ischemické príhody vzniklé z jiných přičin. Jejich mortalita je dvojnásobná, $25 \%$ pacientů tak umírá do jednoho měsíce, polovina pak do jednoho roku. Mají horší průběh a častější recidivy, $\checkmark$ neposlední řadě je to i prríčina eskalujících nákladů.

\section{Skórovací systém CHADS $_{2}$}

Pravděpodobnost, že nemocný s fibrilací síní dostane CMP, se dá odhadnout na základě prítomnosti rizikových faktorů. Za účelem kvantifikace rizika vznikla řada skórovacích systémů. Nejznámější a dosud nejpoužívanější je systém $\mathrm{CHADS}_{2}$. Tento název je akronymem posuzovaných rizikových parametrů: $C$ - cardiac failure (srdeční selhání), $\mathrm{H}$ - hypertension (hypertenze), A - age (věk nad 75 let), D - diabetes mellitus, $S_{2}$ - stroke-doubled (CMP či TIA transitorní ischemická ataka, dvojnásobně). Přítomnost každého rizikového faktoru se počítá za jeden bod, pouze anamnéza prodělané CMP či TIA je hodnocena dvěma body. $U$ tohoto systému však až př́liš mnoho pacientů spadalo do šedé zóny, když byli vyhodnoceni jako středně rizikoví a nebylo jasné, zda u nich je či není antikoagulační léčba doporučena. I proto guidelines pracují s modifikovaným skóre $\mathrm{CHA}_{2} \mathrm{DS}_{2}$-VASc. Věku nad 75 let jsou zde prriřazeny dva body, navíc se prridává jeden bod za cévní onemocnění - vascular disease (překonaný infarkt myokardu, postižení periferních tepen, sklerotické postižení aorty), věk - age (65-74 let) a ženské pohlaví - sex category. Maximální hodnota je tak o tři body vyšší, ale jinak zůstávají použití i interpretace stejné.

\section{Nemalé nevýhody warfarinu}

Riziko CMP při fibrilaci síní výrazně redukuje antikoagulační léčba, základním prípravkem je zde perorální antikoagulans warfarin. $V$ metaanalýze studií zabývajících se warfarinem se ukazuje, že správná warfarinizace umí snížit pravděpodobnost vzniku CMP u pacientů s touto arytmií o dvě třetiny a riziko úmrtí snižuje o $26 \%$. Tato data zní skvěle, warfarin ale má bohužel celou řadu nevýhod. Správné vedení léčby komplikuje zejména jeho velmi úzké terapeutické rozmezí. Dávkování warfarinu musí být takové, aby se hodnota INR pohybovala $v$ rozmezí $2-3$. Pacient s INR $<2$ je nedokonale chráněn, s INR $<1,3$ má stejné riziko ischemické CMP, jako kdyby warfarin vůbec neužíval. Naopak INR > 4 s sebou nese významné 
a rychle rostoucí riziko krvácení, včetně nitrocerebrálního, a rychle tak narưstá nebezpečí hemoragických CMP.

Udržet pacienta $v$ terapeutickém okně daném INR je obtížné. „I v kontrolovaném prostředí klinických studií mají tuto hodnotu v požadovaném rozmezí pouze dvě třetiny nemocných, $v$ běžné praxi to není ani polovina. To rozhodně nestačí. Navíc, abychom mohli prohlásit léčbu za účinnou, musí být INR v terapeutickém rozmezí po většinu času warfarinizace. $K$ tomu používáme ukazatel TTR (time in the therapeutic range), který nám říká, kolik procent $z$ řady měření bylo $v$ terapeutickém rozmezí. TTR musí být alespoň $65 \%$, jinak pacient není dobře chráněn. Pokud je INR v požadovaném intervalu jenom po jedné třetině času, pacient má stejnou prognózu, jako by warfarin vůbec neužíval," varuje J. Hradec.

Svůj vliv má i značná interindividuální variabilita odpovědi na warfarin. Gen pro reduktázu vitaminu $K$, přes kterou lék působí, je značně polymorfní. Jednotlivé osoby jsou tak k němu rozdílně citlivé. Kromě toho hraje roli polymorfismus genu pro cytochrom CYP2C9, kterým je warfarin odbouráván. Populace se tak dělí na rychlé, středně rychlé a pomalé metabolizátory. Rozdíl aktivity warfarinu mezi rychlým a pomalým metabolizátorem je až třicetinásobný. Pacienti, kteří mají kombinace pomalého metabolizátora s vysokou citlivostí k warfarinu, musejí dostávat několikanásobně menší dávky než např́klad rychlí metabolizátoři s nízkou citlivostí. Bohužel se neosvědčila genetická typizace, takže jediným způsobem jak zjistit vhodnou dávku, je provést řadu měření INR a průběžně upravovat dávkování. Situaci komplikují farmakokinetické vlastnosti warfarinu, kdy se změna dávky projeví na INR až v řádu několika dnů.

Všechny tyto limitace vedou $k$ tomu, že $v$ současné době bohužel warfarin dostává jenom polovina indikovaných pacientů. $K$ tomu je nutné přičíst ještě fakt, že polovina z nich je warfarinizována špatně. „Pacienti, kterým se bojíme warfarin napsat, jsou většinou ze skupiny starších nemocných, kteří mají poruchy kognitivních funkcí, bydlí často sami nebo nemohou docházet pravidelně na kontroly. Právě takoví pacienti ale mají větší riziko ischemické mozkové příhody. Naštěstí už dnes máme alternativu, a to prímé inhibitory faktoru Xa a prímé inhibitory trombinu. Budoucnost prevence TE příhod u fibrilace síní tak vidím daleko nadějněji než současnost a minulost," uzavírá optimisticky své sdělení J. Hradec.

\section{Sekundární prevenci je třeba zahájit co nejdřive} Jako druhý řečník vystoupil MUDr. Ondřej Škoda, primář Neurologického oddělení Nemocnice Jihlava, který danou problematiku shrnul z pohledu neurologa: „Tromboembolická CMP je akutní onemocnění, které umíme velmi rychle diagnostikovat sonografickým potvrzením okluze mozkové tepny s následným angiografickým ověřením. Přes 80 \% mozkových příhod připadá na mozkové ischemie a jejich podíl dle údajů American Association of Neurology i dle čerstvých dat z ČR stále stoupá," říká na úvod. Příčinou tohoto trendu podle něj mưže být již zmiňované stárnutí populace, kdy roste počet nemocných nejen s fibrilací síní, ale třeba i s onemocněním velkých tepen. Z hlediska etiologie ischemických příhod patři kardioembolické CMP mezi nejčastější. Stejně, přibližně
$30 \%$, jsou zastoupeny ty, u kterých je zdroj trombu ve velkých a středních tepnách, a ty, kde je důvodem onemocnění malých tepen. I na pečlivém pracovišti je zhruba u $5 \%$ prrípadů uváděn závěr, že jde o idiopatickou př́icinu - tito pacienti naštěstí mají relativně nejnižší riziko recidiv.

„Zvláště významnými rizikovými faktory pro vznik CMP jsou arytmie, v první řadě fibrilace síní, dále pak například stenózy magistrálních mozkových tepen, které se snažíme velmi pečlivě, ale selektivně indikovat k desobliteraci. Důležité je si uvědomit, že riziko vzniku nové CMP u pacienta, který již minimálně jednou príhodu prodělal, je největší v prvním měsíci po první atace, silně zvýšené je během prvního půl roku a následně činí asi $5 \%$ ročně. To znamená, že se riziko snižuje rychle a nelineárně. Chceme-li tedy pacientovi pomoci, musíme zahájit sekundární prevenci co nejdříve. Neměli bychom zapomínat ani na pacienty po TIA, a také u nich by měla být provedena sekundárně preventivní opatření. Standardní léčbou je antiagregace, antikoagulace a léčba případných dalších rizikových faktorů. Zde uvedu příklad desobliterace nebo angioplastiky symptomatických stenóz, " připomíná O. Škoda. Naštěstí jsou k dispozici metody, které usnadňují vyhledávání pacientů s největším rizikem. Př́kladem může být transkraniální sonografie, která nachází embolické signály a upřesňuje jejich zdroj.

A jak je organizována péče o pacienty s CMP? „Od roku 2010 je systém nastaven tak, že při podezření na akutní CMP musí být ihned zavolána rychlá záchranná služba, pacient musí být brán, jako by iktus skutečně měl, a musí být poslán do nemocnice s iktovým nebo komplexním cerebrovaskulárním centrem. Zprvu bylo v České republice vybráno deset komplexních a 23 iktových center, v současnosti probíhá druhé kolo tvorby sítě, a přibýt by tak mělo až dalších deset center. To už by mohl být konečný stav, který pokryje potřeby tohoto státu," popisuje O. Škoda.

\section{Nová perorální antikoagulancia - výrazná šance pro pacienty}

Pokud pacient splňuje časová kritéria pro zahájení rekanalizace, tedy přichází do 4,5 hodiny od začátku příhody, musí být směrován na pracoviště, které je schopné zákrok provést. Nejčastěji je nemocnému nabídnuta systémová trombolýza, k dispozici již jsou také mechanické metody nebo selektivní intraarteriální podání trombolytika. Při časné rekanalizaci má samozřejmě pacient nejlepší vyhlídky na dobrou úpravu. $V$ těsné návaznosti na diagnostiku a akutní léčbu zahajujeme i sekundární prevenci. Specializovaná centra mají k dispozici cerebrovaskulární poradny, které mohou pacienty i nadále dispenzarizovat.

Vedle trombolýzy je jedinou akutní léčbou, která vykazuje sice malou, ale prokázanou redukci mortality a recidiv, antiagregace. Nezávisle na terapeutickém postupu má pro pacienta význam pobyt na iktové jednotce, včasně zahájená rehabilitace a preventivní dávky nízkomolekulárního heparinu k prevenci hluboké žilní trombózy a plicní embolizace. Nemocný musí být samozřejmě léčen i z hlediska prípadných komplikací. Antiagregační léčba je doporučována všem pacientům, kteří nejsou indikováni k antikoagulaci, dle platných doporučení by měli dostávat 
bud' kombinaci kyseliny acetylsalicylové (ASA) a dipyridamolu, anebo samotný clopidogrel jako léky první volby. „Alternativou zůstává stále samotná ASA, což je z ekonomických důvodů poměrně častá realita. Kombinace ASA a clopidogrelu není doporučena $k$ dlouhodobému podávání s výjimkou specifických situací. U pacientů, u kterých došlo $\mathrm{k}$ iktu, přestože už antiagregační terapii dostávali, by se měla znovu posoudit patofyziologie rizikových faktorů a př́padně spíše vyměnit léky než navyšovat jejich dávku, " uvádí $O$. Škoda a dodává, že perorální antikoagulační léčba je doporučena u všech ischemických iktů vzniklých ve spojitosti s fibrilací síní: „Nedoporučuje se pouze u nemocných, kteři ji nemohou dostávat z důvodů komorbidit, pádů, špatné spolupráce, nekontrolované epilepsie nebo krvácení v anamnéze. Samotný vyšší věk není kontraindikací, protože víme, že s vyšším věkem se zvyšuje i riziko CMP. Bez spojitosti s fibrilací síní podáváme antikoagulační léčbu pacientům s vysokým rizikem recidivy onemocnění a předpokládaným centrálním zdrojem embolizací. Většinou jde o príhody způsobené kardiologickou prríčinou nebo třeba fuziformním aneurysmatem bazilární arterie či disekcí velké tepny. Antikoagulační léčbu můžeme podávat i pacientům s rizikem paradoxní embolizace."

Doba zahájení terapie je stále předmětem diskuse, $v$ doporučeních většinou přesný čas není. Soulad panuje $v$ tom, že po drobném iktu nebo transitorní príhodě je možné začít prakticky ihned, ideálně už během hospitalizace v iktovém centru. „Začínáme s nízkomolekulárním heparinem a záhy standardně přecházíme na warfarin. $U$ rozsáhlejších príhod by se mělo počkat kolem čtyř týdnů, ale záleží na konkrétním pacientovi. Antikoagulační léčba by se měla užívat dlouhodobě, alespoň však tř̌i měsíce po kardiogenním iktu. Bohužel řada pacientů warfarin dostat nemůže. Častými příčinami jsou pády, nespolupráce pacienta nebo např́klad sekundární epilepsie, která se někdy vyvine právě kvůli CMP. Šancí jsou nová perorální antikoagulancia, která působí přímo na faktor Xa či trombin. Proti warfarinu mají radu výhod. Podle klinických studií vykazují stejnou nebo lepší účinnost a stejný nebo lepší bezpečnostní profil v porovnání s warfarinem, ale jejich nástup účinku je rychlý, dávka většinou fixní, interakce s jinými léčivy jsou mnohem méně četné a není nutná monitorace," uzavírá $O$. Škoda. Navíc mají relativně krátký poločas, takže jejich jedinou relativní nevýhodou zưstává, že ještě většinou nemají specifická antidota. $V$ tomto ohledu znamenají nová perorální antikoagulancia výraznou šanci pro pacienty, kteří warfarinem být léčeni nemohli, protože pro ně představoval príliš rizikovou variantu, anebo u nich nebylo možné udržet potřebné INR.

MUDr. Martin Vaněk

\section{Co zjistila studie ARISTOTLE?}

$V$ rámci brněnského $X X$. výročního sjezdu ČKS zaznělo v sekci „Hot Lines" zajímavé sdělení věnované výsledkům studie ARISTOTLE s apixabanem podávaným v prevenci vzniku CMP a systémové embolizace u fibrilace síní. Tato studie přinesla vskutku impozantní výsledky, které v jistém smyslu předčily očekávání jejích investigátorů.

I když je warfarin zlatým standardem, který se používá již více než 50 let, jeho podávání má řadu nevýhod, především interindividuální variabilitu, riziko významných farmakologických i potravinových interakcí, nutnost monitorace a problematické udržení terapeutického rozmezí INR. Důsledkem těchto problémů je v reálné praxi nedostatečná antikoagulace $u$ indikovaných pacientů. Odhaduje se, že především z obav z navození krvácení je v současnosti warfarinem léčena přibližně jen polovina $z$ indikovaných nemocných, a u těchto léčených je navíc účinné koncentrace dosaženo opět jen ve zhruba polovině měření.

Apixaban byl zkoumán v řadě studií, závěry nejpodstatnější z nich - studie ARISTOTLE - byly prezentovány na podzim loňského roku. Z výsledků předchozích studií se zdálo, že by apixaban mohl být účinnější než warfarin i u pacientů s nevalvulární fibrilací síní. Potvrzení měla přinést studie ARISTOTLE, která sledovala více než 18000 pacientů. Vstupními kritérii byl vedle fibrilace síní věk nad 75 let nebo předchozí cévní mozková prríhoda (CMP) či transitorní ischemická ataka anebo srdeční selhání s ejekční frakcí $\leq 40 \%$ či hypertenze nebo diabetes mellitus. Podstatné je, že $z$ důvodů bezpečnosti pacientů bylo při plánování studie rozhodnuto, že se bude testovat relativně nízká dávka apixabanu, tedy dvakrát $5 \mathrm{mg}$, protože pưvodním cílem studie nebylo prokázat, že je apixaban lepší, ale že při větší bezpečnosti není horší než warfarin. Zpočátku šlo tedy o potvrzení předpokladu, že apixaban

bude stejně účinný v prevenci vzniku CMP a systémové embolizace jako warfarin v terapeutickém rozmezí, bude mít ale menší počet krvácivých komplikací. Studie byla mezinárodní, multicentrická a zúčastnila se jí i Česká republika, která zařadila 165 pacientů. Průměrný věk nemocných byl 70 let, $35 \%$ tvořily ženy, $43 \%$ neužívalo předem warfarin a u $66 \%$ bylo skóre $\mathrm{CHADS}_{2} \geq 2$ (průměr tohoto skóre pak činil 2,1 ). Průměrná doba sledování byla 1,8 roku a během této doby předčasně ukončilo testovanou medikaci $25,3 \%$ pacientů na apixabanu vs. $27,5 \%$ na warfarinu $(p<0,001)$.

Podání apixabanu snížilo výskyt CMP a systémové embolizace o $21 \%(p<0,01)$ v porovnání s warfarinem. Také z pohledu bezpečnosti byl apixaban lepší než dosud užívaný zlatý standard, modernější antikoagulační léčba snížila počet krvácivých komplikací o $31 \%(p<0,001)$, a ve prospěch apixabanu hovoří dokonce pokles úmrtnosti o $11 \%$ $(p=0,047)$. Výsledky studie ARISTOTLE byly pro všechny investigátory velkým překvapením. Nejen že byla prokázána non-inferiorita apixabanu, ale ukázalo se, že apixaban je výrazně lepší než warfarin, a to i v této relativně nízké dávce. Non-inferiorita je tedy naprosto bez diskusí, namísto toho studie dokumentovala superioritu apixabanu v porovnání s warfarinem na jednoprocentní hladině významnosti. Potvrdilo se také, že apixaban je výrazně bezpečnější, a to na jednopromilové hladině významnosti. Také v analýzách všech podskupin byl patrný trend ve prospěch apixabanu a nenašla se žádná skupina nemocných, u níž by byl apixaban horší než warfarin. Výsledky potvrzují, že léčba apixabanem oproti warfarinu zabránila šesti cévním mozkovým přihodám (čtyřem hemoragickým a dvěma ischemickým), 15 krvácením a osmi úmrtím na 1000 pacientů za necelé dva roky sledování. 